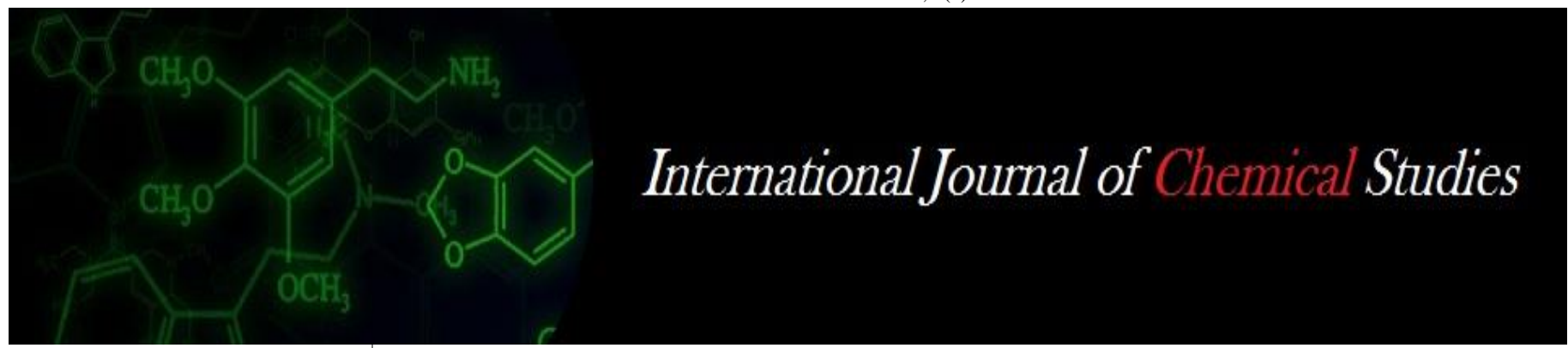

P-ISSN: 2349-8528

E-ISSN: 2321-4902

www.chemijournal.com

IJCS 2020; 8(2): 698-702

(C) 2020 IJCS

Received: 10-01-2020

Accepted: 12-02-2020

\section{Kumari Shiwani}

School of Agriculture,

Abhilashi University, Mandi,

Himachal Pradesh, India

\section{Perspectives of grafting in Solanaceous vegetables: A review}

\section{Kumari Shiwani}

DOI: https://doi.org/10.22271/chemi.2020.v8.i2k.8848

\begin{abstract}
Vegetables are nutritionally rich, high-valued crops and remunerative enough to replace subsistence farming. However, vegetables especially Solanaceous vegetables are highly sensitive to biotic and sudden irregularities in weather factors at any phase of crop growth can affect the normal growth, flowering, fruit development and subsequently the yield. Grafting in vegetable has emerged as a promising surgical alternative over relatively slow conventional breeding methods aimed at increasing tolerance to biotic and abiotic stresses thus enabling expansion of commercial production of vegetable in problematic soils. Accordingly, the aim of the current review is to reassess the perspective of grafting in above said group of vegables.
\end{abstract}

Keywords: Grafting, Solanaceous vegetables

\section{Introduction}

India is the world's second largest producer of vegetable crops after China, with increasing population, there is need to boost the production of vegetable crops. Vegetable crops are very sensitive to biotic stresses and climatic vagaries, so fluctuation in climatic parameters or incidence of any biotic stress at any phase of crop growth can affect the normal growth, flowering, fruit development and subsequently the yield (Afroza et al., 2010) ${ }^{[1]}$. Grafting is surgical approach to combat these biotic and abiotic stresses by using resistant rootstock. The process involves union of two parts (a rootstock and scion) together from two different plant parts to form a single, living plant. As the main drives behind the expansion of vegetable grafting have been the resistance to soilborne pathogens, tolerance to abiotic stresses and increase in yields. Grafting in vegetable has emerged as a promising and an alternative tool to the relatively slow conventional breeding methods aimed at increasing tolerance to biotic and abiotic stresses (Bahadur et al., 2015) ${ }^{[7]}$.

Applications of grafting have expanded mainly in two families, the Cucurbitaceae and the Solanaceae, both of which comprise major vegetable crops. The first attempt in vegetable grafting was done by grafting watermelon (Citrullus lanatus) onto pumpkin (Cucurbita moschata) rootstock in Japan and Korea in the late 1920s (Leonardi, 2016) ${ }^{[30]}$. In global, this method of propagation has gained much fame in grafting of tomato, eggplant and pepper onto vigorous and disease-resistant rootstocks to ensure adequate yields where salinity, biotic stresses, and environmental stresses/or unfavorable growing temperatures limit productivity. Further inventions are mechanized and robotic grafting has given a fillip to this novel ecofriendly approach.

\section{Achievements in grafting in India}

Many private and public sector institutes in India have initiated progressive research works in this direction dealing various locations specific biotic and abiotic stresses.

a) In public sector, grafting work has been started in IIHR, Bangalore to select best rootstocks for water logged conditions by Dr. RM Bhatt and his associates. The first ever initial short course on vegetable grafting was started in 2013 at IIHR, Banglore (Kumar et al., 2015) ${ }^{[28]}$

b) The Momordica cochinchinensis, a dioecious vegetable crop is utilizing for grafting with male as rootstock and female plant as scion in the NBPGR regional station, Trissur, Kerala. The female plants were grafted on to the male plants to achieve higher production. 
c) Department of Vegetable Science and Floriculture, Chaudhary Sarwan Kumar Himachal Pradesh Krishi Viswavidyalaya, Palampur, Himachal Pradesh is also working on grafting mainly against bacterial wilt which emerged as one of the devastating problems in some parts of the state and limiting the cultivation of Solanaceous vegetables in particular.

d) Department of Vegetable Science, ASPEE College of Horticulture \& Forestry, NAU, Navsari, Gujarat started a work on grafting during 2013-14 with major emphasis to work out the feasibility of growing brinjal as well as tomato under high rainfall conditions of South Gujarat (Kumar et al., 2018) ${ }^{\text {[29] }}$.

e) Very recently, scientists of AICRP on Vegetable Crops, Bidhan Chandra Krishi Viswavidyalaya, West Bengal have initiated the grafting of cultivated brinjal on the most tolerant wild rootstocks Solanum torvum and Solanum sisymbriifolium against bacterial wilt after a series of cross inoculation with most virulent strains of Pseudomonas solanacearum (Kumar et al., 2018) ${ }^{[29]}$.

f) Among private sector(s) VNR Seeds Pvt. Ltd., Raipur (Chhattisgarh) is one of the pioneer workers in grafting and working in close association with Asian Vegetable Research and Development Centre (AVRDC), Taiwan. They have now started their commercial venture in this aspect and are supplying grafted seedlings to the farmers within and adjoining states depending upon requirement of the farmers (Kumar et al., 2018) ${ }^{[29]}$.

Important consideration for successful vegetable grafting 1. Selection of potential rootstock/scion: Select the desirable rootstock and scion having the same stem size (diameter). Grafting should be done at 2-3 true leaf stage.

2. Compatibility between rootstock and scion: Compatible rootstock and scion minimizes the mortality rate even in later stage of growth. Rapid callus formation takes place between scion and rootstock and leads the formation of vascular bundles.

3. Grafting aids: Commonly used aids to perform grafting i.e. Grafting clips, tubes, pins, and grafting Blade.

4. Screening house: Used for growing seedlings prior to grafting. It should be constructed with 60 -mesh nylon net. Arrange double door, the upper half of the structure should be covered with a separate UV resistant polyethylene to prevent UV light penetration.

5. Healing of grafts union: Healing is most critical to provide favourable conditions to promote callus formation of grafted seedlings. In healing chamber, temperature should be 28-29 ${ }^{\circ} \mathrm{C}$ with $95 \%$ relative humidity for 5-7days in partially shaded place (darkness for 1-2 days) to promotes callus formation at union. It helps in formation of better graft union by reducing transpiration, maintains high humidity, maintains optimum temperature and reduces light intensity. The main aim is to initiate environment by controlling temperature and humidity.

6. Acclimatization of the grafted plants: After the callus has formed and the wounded surfaces are healed, plants may be put under a mist system, greenhouse or placed under a clear plastic cover for acclimatization to prevent leaf burning and wilting.

\section{Methods of grafting}

The familiar methods used for vegetable are:

1. Cleft grafting: This is widely used method of grafting in Solanaceous crops. Here scion plants are pruned to have 1-3 true leaves and the lower stem is cut to slant angle to make a tapered wedge and clip is placed to make contact between scion and rootstock after placing scion into the split made (Johnson et al., 2011) ${ }^{[21]}$.

2. Tongue approach/Approach grafting: This method most widely used by farmers and small nurseries. This method requires more space and labor compared to other methods but high seedling survival rate can be attained even by beginners. Grafted seedlings have a uniform growth rate but it is not suitable for rootstocks with hollow hypocotyls.

3. Hole insertion/ Top insertion grafting: This is most popular method in cucurbits scion and rootstock should have hollow hypocotyls are preferred in this method. To achieve a high rate of success, relative humidity should be maintained at $95 \%$. The optimum temperature should maintain at $21-36 \circ \mathrm{C}$ up to transplanting. One person can produce 1,500 or more grafts/day.

\section{One cotyledon/ Splice grafting}

It has recently been adopted by commercial seedling nurseries and applicable to most vegetables (Sakata et al., 2006) ${ }^{[36]}$. The grafted plants should be maintained in the dark at $25^{\circ} \mathrm{C}$ and $100 \%$ humidity for three days for graft union formation. This method has been developed for robotic grafting of cucurbits.

5. Tube grafting: It is similar to slant grafting except that in this method root stock \& scion joined are held with an elastic tube instead of clips. It is more popular in tomato and brinjal.

6. Pin grafting: Pin grafting is basically the same as the splice grafting. Instead of placing grafting clips, especially designed pins are used to hold the grafted position. The pins are made of natural ceramic so it can be left on the plant without any problem.

\section{Grafting of solanaceous vegetable crops}

Grafting in tomato was introduced commercially in 1960s. While it can be expensive, grafting onto resistant rootstocks can provide an effective solution to some soil-borne diseases where breeding has not yet produced varieties with effective levels of disease (Anonymous, 2013) ${ }^{[3]}$. However, there are production problems like weeds, insect pests and diseases including late blight and Fusarium wilt with high rainfall, flooding, and high temperatures can significantly reducing the yield. Grafting is one of the techniques to solve abovementioned problems exist in tomato (Pogonyi et al., 2005) ${ }^{[34]}$. Grafting sweet pepper onto selected rootstocks of sweet pepper and chilli (hot) pepper can minimize problems caused by flooding and tolerance to bacterial wilt, Phytophthora blight and root knot nematodes (Anonymous, $2009)^{[2]}$. Brinjal is widely cultivated in tropical and temperate regions around the world and is open to grafting. It is prone to numerous diseases and parasites, in particular to Ralstonia solanacearum, Fusarium and Verticillum wilts, nematodes and insects. It has been reported that brinjal grafted onto wild Solanum species and other resistant rootstocks is an efficient technique to control various pathogens (King et al., 2010) ${ }^{[25]}$. 


\section{Graft compatibility and survival rate}

There are many reasons why rootstocks affect scion fruit quality. The most obvious is rootstock/scion incompatibility, which induces undergrowth and/or overgrowth of the scion, leading to decreased water and nutrient flow through the grafted union, ultimately causing wilting (Davis et al., 2008b) [13]. Nevertheless, to get positive effect of grafting on vegetable quality, rootstock/scion combinations should be carefully selected for specific climatic and geographic conditions (Davis et al., 2008a) ${ }^{[12]}$.

\section{Effects of grafting on quantitative characters}

In tomato, grafting resulted in the formation of more number of internodes and flowers in outdoor cultivation and number and total weight of fruits in polyhouse cultivation (Voutsela $e t$ $a l ., 2012)^{[42]}$. An increase in yield of tomato due to grafting reported by Khah et al. (2006) ${ }^{[23]}$; Kleinhenz et al. (2009) and Gebologlu et al. (2011) ${ }^{[17]}$. A report of grafted brinjal plants on S. torvum were significantly more vigorous, as measured by plant height, stem diameter and root biomass than the control plants by Bletsos et al. (2003) ${ }^{[8]}$. High fruit weight and marketable fruit yield were reported by Kumar et al. (2016) ${ }^{[27]}$ in capsicum which was grafted onto chilli rootstock PI201232. Though, the economic feasibility has to be studied more before application of the techniques.

\section{Effects of grafting on qualitative characters}

A study showed that fruit quality varies with both cultivar and rootstock and more vigorous plants tend to be better quality fruit and reported that the solutes associated with fruit quality are translocated in the scion through the xylem, whereas quality traits, e.g. fruit shape, skin colour, skin or rind smoothness, flesh texture and colour and soluble solids concentration are influenced by the rootstock (Nicoletto et al., 2013) ${ }^{[31]}$. In soilless tomato cultivation, grafted plants had higher marketable yield, fruit quality and $\mathrm{pH}$ content of fruits depending on rootstocks. The vigour of the scion predominated over the foliar control in terms of the nutritional state of $\mathrm{Fe}$ in the tomato plants (Rivero et al., 2004) ${ }^{\text {[35]. In }}$ contrast grafting of eggplant on Solunum torvum and Solunum Sisymbriifolium negatively affected vitamin C content, firmness and some sensory attributes but overall impression was not influenced (Arvanitoyannis et al., 2005) ${ }^{[5]}$. Flores et al. (2010) ${ }^{[16]}$ found that fruit from 'Kyndia', an indeterminate commercial cultivar, grafted onto 'UC82B', a determinate processing cultivar had elevated TSS compared to self-grafted tomato plants. Khah et al. (2006) ${ }^{[23]}$ also stated difference in total soluble solids and fruit juice $\mathrm{pH}$ on grafted tomato as compared to non grafted plants. However, Di-Gioia et al. (2010) ${ }^{[14]}$ recorded no significant differences in total soluble solids by tomato 'Oxheart' grafted onto 2 interspecific $S$. lycopersicum $\times S$. habrochaites and also found that vitamin $\mathrm{C}$ content also decreased by $14-20 \%$, if tomato plants grafted onto Beaufort F1 and Maxifort F1. Colla et al. (2008) [11] reported no significant difference in titrable acidity and $\mathrm{pH}$, when two pepper hybrids were grafted on five commercial rootstocks Snooker, Tresor, RX360, DRO8801 and 97.9001. So, there is necessitating to further studies for application of grafting techniques in qualitative traits.

\section{Effects of grafting on biotic stresses}

The primary purpose of grafting vegetables worldwide has to provide resistance to diseases and insect-pests. Soil borne diseases (Fusarium wilt, Verticillum wilt and bacterial wilt) and nematodes, are some of the biotic stress cause damages in vegetable production especially in continuous cropping of greenhouses/ polyhouses. AVRDC (Anonymous, 2009) ${ }^{[2]}$, recommends eggplant accessions EG195 and EG203. They are resistant to damage caused by bacterial wilt, root-knot nematode, and tomato Fusarium wilt. Grafted brinjal which was planted on infected soil with wilt disease produced better yield over the non-grafted plants (Bletsos et al., 2003) ${ }^{[8]}$. The use of Solanum torvum as rootstock was reported to provide resistance to Verticillium wilt, Fusarium wilt, bacterial wilt and root knot nematode though generally grafting controls the common disease like Fusarium wilt in tomato plants (King et al., 2008) ${ }^{[24]}$. According to AVRDC (Anonymous, 2009) ${ }^{[2],}$ chili accessions PP0237- 7502, 0242-62 and Lee B for grafting which are resistant to damage caused by bacterial wilt and Phytophthora blight. Pepper scion ('Nokkwang') grafting onto lines ('PR 920', and 'PR 921', and 'PR 922') resistant to both Phytophthora blight and bacterial wilt showed greater rate of survival (Jang et al., 2012) ${ }^{[20]}$. When the susceptible commercial pepper variety (cv. Gedon) grafted onto rootstocks resistant to Rhizoctonia root rot and Fusarium wilt grown in the infested soil was less attacked with wilt disease, while un-grafted plants were severely infected (Attia et al., 2003) ${ }^{[6]}$.

\section{Effects of grafting on abiotic stresses}

Abiotic stress significantly affects tomato production both in open field and greenhouse/ polyhouse condition. These include, too cold, wet or dry, hypoxia, salinity, heavy metal contaminations, excessive and insufficient nutrient availability, and soil $\mathrm{pH}$ stress. These conditions cause various physiological and pathological disorders leading to severe crop loss (Savvas et al., 2010) ${ }^{[38]}$. To induce resistance against low and high temperatures, grafts were generally used. Grafting influences absorption and translocation of phosphorus, nitrogen, magnesium, and calcium. The Improved nutrient uptake in grafted seedlings increases photosynthesis rate of plants, which is particularly noticeable under less than optimal growing conditions such as weak sunlight and low $\mathrm{CO}_{2}$ content in solar greenhouses during winter months (Hu et al., 2006) ${ }^{[19]}$. It has been suggested that these conditions allow grafted plants to produce higher yields, sometimes with improved fruit quality (Xu et al., 2006) ${ }^{[43] .}$ Grafting minimizes the negative effect of boron, copper, cadmium, and manganese toxicity (Savaas et al., 2010). Venema et al. (2008) ${ }^{[41]}$ studied the impact of grafting of tomato (Solanum lycopersicum Mill.) onto the rootstock of a cold-tolerant high altitude accession of a related wild species (Solanum habrochaites LA 1777) with respect to higher root mass ratios and relative growth rate, found that $S$. habrochaites LA 1777 appeared to be a valuable germplasm pool to improve the low-temperature tolerance. Grafting tomato plants for increased salinity tolerance is a promising practice to improve the crop performances in saline soil conditions (Colla et al., 2010) ${ }^{[10]}$. Chilli gave highest yield under high-temperature conditions when grafted on sweet pepper rootstocks (Palada and $\mathrm{Wu}, 2009$ ). Brinjal roots can survive for days under water, as a result most of brinjal lines may graft successfully with tomato lines that will maintain high yields and fruit quality of the scion variety.

\section{Physiological disorder}

Blossom end-rot (BER), the most typical tomato disorder (Ho and White, 2005), was invariably reduced in tomato grafted on rootstocks 'Brigeor,' 'Maxifort,' and LA1777(S. habrochaites), and under different environmental conditions 
shaped by factors such as salinity, potassium nutrition, suboptimal temperature, and light conditions (Krumbein and Schwarz, 2013 and Ntatsi et al., 2014) ${ }^{[32]}$. Moreover, reduction in BER incidence with grafting was pronounced under stress conditions in comparison to both non and selfgrafted scions. Decrease in BER was mainly related to the rootstock genotype e.g., the BER incidence in 'Classy,' a medium round type tomato was more diminished when grafted on the rootstock 'Brigeor' compared to 'Maxifort' or self-grafted plants. The BER reduction was also influenced by rootstock-scion interaction e.g., it was decreased to a greater extent when cherry tomato 'Piccolino' was used as a scion. Under certain conditions, the use of a rootstock may raise the BER incidence. Rootstock 'Edkawi,' although known as salinity-tolerant, as well as eggplant rootstocks, lower the uptake and transport of $\mathrm{Ca}$ ions into the fruits compared with self-grafted tomato. Results indicate that the incidence of BER is reduced by grafting when Ca uptake and transport into the fruits is improved (Fan et al., 2011 and Savvas et al., 2017) ${ }^{[15,39]}$.

\section{Period of flowering and harvest}

It was observed that non-grafted plants bloomed earlier than grafted plants. The late flowering in grafted plants might be due to the growth of scion plants was interrupted for a week nearly due to grafting and prolonged vegetative growth which has been also reported by Suthar et al. (2005) ${ }^{[40]}$ in brinjal for delayed flowering in grafted plants. It increases the plant vigour and extending the duration of economical harvest time. Grafting is also conducted to study the movement of some endogenous flowering substances across the graft union, proven that the flower-inducing stimuli controlled by photoperiod moved easily through the graft union, while the stimuli induced by vernalization did not (Chailakhyan and Khrianin, 1987) ${ }^{[9]}$.

\section{Recent innovations of vegetable grafting}

Now a day's many new innovations developed to perform grafting in vegetables, few are summarised below:

i) Grafting Robots: A full automation model developed in the Netherlands can graft 1,000 tomato or eggplant seedlings per hour and has more functions such as automatically selecting matching rootstock and scion seedlings, which is a crucial process to increase the success rate. According to Kobayashi et al. (2009), the first commercial model of a grafting robot (GR800 series; Iseki \& Co. Ltd., Matsuyama, Japan) became available for cucurbits in 1993 and there were various semi- and fully automated grafting robots. Recently Sarswat and Kumar (2019) [37] worked on the standardization of robotic grafting in polyhouse bell pepper in CSKHPKV, Palampur, Hiamchal Pradesh.

ii) Micro-grafting: In vitro grafting using very small or micro explants $\left(<1 / 1000\right.$ th $\mathrm{mm}^{3}$ ) from meristematic tissues to eliminate the viruses from infected plants. Micro grafting has been used in herbaceous plants to evaluate the physiology of grafting and determine the chemical basis of cell to cell contacts. This method provides rapid propagation of virus free plants although, it is expensive.

iii) Double grafted: The Pomato is a chimeric plant produced by grafting tomato scion on potato rootstock, with tomato growing on vines while potato tuber grow under the soil of the same plant. Arefin et al. (2019) [4] reported that all possible graft combinations showed excellent graft compatibility, however the potato varieties, Cardinal and Asterix and the tomato variety BARI tomato 11 showed the best performance for growth and yield attributes plant resultant of vegetable grafting. In this tomato scions were grafted onto potato rootstocks by cleft grafting.

\section{Conclusion}

Grafting is a method of plant propagation, done by utilizing selective rootstock and scion combinations for tolerance against soil borne diseases that directly influences the production of vegetable crops. As a result, increased net returns achieved in wide range of soil and environmental stress conditions even in off season. It is a rapid alternative means to the moderately slow breeding methodology. In recent days, grafting application leads the limit use of harmful soil disinfectants which minimizes the toxic residues in vegetables and environmental pollution. Hence, it is suggested that, by adopting modern innovations and indigenous wild relatives, we can realize commercial use of grafting to attain the low input sustainable horticulture in future.

\section{References}

1. Afroza B, Wani KP, Khan SH, Jabeen N, Hussain K, Mufti S, Amit A Various technological interventions to meet vegetable production challenges in view of climate change. Asian Journal Horticulture. 2010; 5(2):523-529.

2. Anonymous. Grafting sweet peppers for the production in the hot-wet season. Asian Vegetable Research and Development Center, Pub. No 09-722, Shanhua, Tainan, Taiwan, 2009, 8.

3. Anonymous. Asian Vegetable Research and Development Centre, Thaiwan, Philippines, 2013.

4. Arefin SM, Zeeba N, Solaiman AH, Naznin M, Md Azad, Tabssum M, Park C. Evaluation of compatibility, growth characteristics and yield of tomato grafted on potato (Pomato). Horticulturae. 2019; 5(2):37.

5. Arvanitoyannis SI, Khah EM, Christakou EC, Bletsos FAR. Effect of grafting and modified atmosphere packaging on eggplant quality parameters during storage. International Journal of Food Science and Technology. 2005; 40:311-322.

6. Attia MF, Arafa AM, Moustafa MA, Mohamed MA. Pepper Grafting, a method of controlling soilborne diseases and enhancement of fruit yield: Improvement of Pepper Resistance to Fusarium Wilt. Egyptian Journal of Phytopathology. 2003; 31(1-2):151-165.

7. Bahadur A, Rai N, Kumar R, Tiwari SK, Singh AK, Rai AK, Singh U, Patel PK, Tiwari V, Singh B. Grafting tomato on eggplant as a potential tool to improve waterlogging tolerance in hybrid tomato. Vegetable Science. 2015; 42(2):82-87.

8. Bletsos F, Thanassoulopoulos C, Roupakias D. Effect of grafting on growth, yield, and Verticillium wilt of eggplant. Horticultural Sciences. 2003; 38(2):183-186.

9. Chailakhyan MK, Khrianin VN. Influence of environmental factors and nutrition on sex determination in plants: A review; In: K. Thimann (ed.). Sexuality in plants and its hormonal regulation. Springer- Verlag, New York, 1987, 31-32.

10. Colla G, Rouphael Y, Cardarelli M, Salemo A, Rea E. The effectiveness of grafting to improve alkalinity tolerance in watermelon. Env. and Exp. Bot. 2010; 68:283-291. 
11. Colla G, Rouphael Y, Cardarelli M, Temperini O, Rea E, Salerno A, Pierandrei F. Influence of grafting on yield and fruit quality of pepper (Capsicum annuum L.) grown under greenhouse conditions. Acta Horticulturae 2008; 782:359-36.

12. Davis AR, Perkins-Veazie P, Hassell R, Levi A, King SR, Zhang X. Grafting Effects on Vegetable Quality. Horticultural Sciences 2008(a); 43(6):1670-1672.

13. Davis RA, Webber CL, Perkins-Veazie P, Ruso V, Galarza SL. Proceedings of the IXth EUCARPIA meeting on genetics and breeding of Cucurbitaceae, INRA, Avignon (France), 2008.

14. Di-Gioia F, Serio F, Buttaro D, Ayala O, Santamaria P. Growth, yield, and fruit quality of 'Cuore di Bue', an heirloom tomato, as influenced by rootstock. Journal of Horticultural Sciences and Biotechnology 2010; 85(6):477-482. doi: 10.1080/ 14620316.2010.11512701

15. Fan M, Bie Z, Krumbein A, Schwarz D. Salinity stress in tomatoes can be alleviated by grafting and potassium depending on the rootstock and K-concentration employed. Sci. Hortic. 2011; 130:615-623.

16. Flores FB, Sanchez-Bel P, Estan MT, MartinezRodriguez MM, Moyano E, Morales B, Campos JF, Garcia-Abellan JO, Egea MI, Fernandez-Garcia N, Romojaro $\mathrm{F}$ and Bolarin MC. The effectiveness of grafting to improve tomato fruit quality. Scientia Horticulturae. 2010; 125:211-217.

17. Gebologlu N, Yilmaz E, Cakmak P, Aydin M, Kasap Y. Determining of the yield, quality and nutrient content of tomatoes grafted on different rootstocks in soilless culture Scientific Research and Essays 2011; 6(10):21472153.

18. Ho L, White PJ. A cellular hypothesis for the induction of blossom end rot in tomato fruit. Ann. Bot. 2005; 95:571-581. doi: 10.1093/aob/mci065

19. Hu CM, Zhu YL, Yang LF, Chen SF, Hyang YM. Acta Botanica Boreali- Occidentalia Sinica. 2006; 26:247-253.

20. Jang Y, Yang E, Cho M, Um Y, Ko K, Chun C. Effect of grafting on growth and incidence of Phytophthora blight and bacterial wilt of pepper (Capsicum annuum L.). Horticulture Environment and Biotechnology 2012; 53(1):9-19.

21. Johnson S, Kreider P, Miles C. Vegetable Grafting Eggplants and Tomatoes Washington State University, 2011, 4.

22. Kaskavalci G, Tuzel Y, Dura O, Oztekyn GB. Ecology 2009; 18(72):23-31.

23. Khah EM, Kakawa E, Mavromatis A, Chachalis D and Goulas C. Effect of grafting on growth and yield of tomato in greenhouse and open-field. Journal of Applied Horticulture. 2006; 8(1):3-7.

24. King SR, Davis AR, Liu W and Levi A. Grafting for disease resistance. Horticulture Science 2008; 43(6):1673-1676.

25. King SR, Davis AR, Zhang $X$ and Crosby K. Genetics, breeding and selection of rootstocks for Solanaceae and Cucurbitaceae. Scientia Horticulturae 2010; 127:106-111.

26. Kleinhenz DM, Francis DM, Young $M$ and Aldrich T. Rootstock Effects on Yield of Grafted Celebrity' Tomato in Ohio. The Ohio State University, Ohio Agricultural Research and Development Center (OARDC), 2010.

27. Kumar P, Negi V, Sharma P, Raj D, Singh A, and Vats V. Grafting tomato and potato rootstocks and its effect on quality traits. Vegetable Science. 2016; 43(2):263-265.
28. Kumar P, Rana S, Sharma P, Negi V. Vegetable grafting: a boon to vegetable growers to combat biotic and abiotic stresses. Himachal Journal of Agricultural Research. 2015; 41(1):1-5.

29. Kumar S, Bharti N, Saravaiya SN. Vegetable Grafting: A Surgical Approach to combat biotic and abiotic stressesA review. Agricultural Reviews. 2018; 39(1):1-11

30. Leonardi C. Vegetable grafting tour introduction. University of Catania, Sicily, Italy, 2016; 23.

31. Nicoletto C, Tosinib F and Samboa P. Effect of grafting and ripening conditions on some qualitative traits of 'Cuore di bue' tomato fruits. Journal Science Food and Agriculture. 2013; 93:1397-1403. doi: 10.1002/jsfa.5906

32. Ntatsi G, Savvas D, Huntenburg K, Druege U, Schwarz D. A study on ABA involvement in the response of tomato to suboptimal root temperature using reciprocal grafts with notabilis, a null mutant in the ABAbiosynthesis gene LeNCED1. Environ. Exp. Bot. 2014; 97:11-21. doi: 10.1016/j.envexpbot.2013.09.011

33. Palada MC, Wu DL. Grafting sweet peppers for production in the hot-wet season. International Cooperators Guide. International Cooperators Guide. Pub. No. 09-722-e. AVRDC (Asian Vegetable Research and Development Centre). Taiwan, 2009.

34. Pogonyi A, PeK Z, Helyes L, Lugasi A. Effect of grafting on the tomato's yield, quality and main fruit components in spring forcing. Acta Aliment. 2005; 34:453-462. doi: 10.1556/aalim.34.2005.4.12)

35. Rivero RM, Ruiz JM, Romero L. Role of grafting in horticultural plants under stress conditions, Journal of plant nutrition. 2004; 27(12):2221-2234.

36. Sakata Y, Sugiyama M, Ohara T, Morishita M. Inûuence of rootstocks on the resistance of grafted cucumber (Cucumis sativus L.) scions to powdery mildew. Journal of Japan Society Horticulture Science. 2006; 75:135-140.

37. Sarswat S, Kumar P. Standardization of robotic grafting in bell pepper for horticultural and quality traits. MSc. Thesis. CSKHPKV, Palampur, H.P, India, 2019.

38. Savvas D, Colla G, Rouphael Y and Schwarz D. Amelioration of heavy metal and nutrient stress in fruit vegetables by grafting. Scientia Horticulturae 2010; 127:156-161.

39. Savvas D, Oztekin GB, Tepecik M, Ropokis A, Tuzel Y, Ntatsi G. Impact of grafting and rootstock on nutrient-towater uptake ratios during the first month after planting of hydroponically grown tomato. J. Hortic. Sci. Biotechnol. 2017; 92:294-302. doi: 10.1080/14620316.2016.1265903

40. Suthar MR, Singh GP, Rana MK and Makhan L. Crop Research Journal. 2005; 30(1):77-79.

41. Venema JH, Dijk BE, Bax JM, Hasselt PR, Elzenga JTM. Graftingtomato (Solanum lycopersicum) onto the rootstock of a high-altitude accession of Solanum habrochaites improves suboptimal-temperature tolerance Environmental and Experimental Botany. 2008; 63:359367.

42. Voutsela S, Yarsi G, Petropoulos SA, Khan EM. The effect of grafting of five different rootstocks on plant growth and yield of tomato plants cultivated outdoors and indoors under salinity stress. African Journal of Agricultural Research. 2012; 7(41):5553-5557.

43. $\mathrm{Xu} \mathrm{CQ}$, Li TL, Qi HY. Effects of grafting on development, carbohydrate content, and sucrose metabolizing enzymes activities of muskmelon fruit. Acta Horticulturae. 2006; 33:773-778. 